\title{
Survey of the Post Harvest Diseases and Aflatoxin Contamination of Marketed Orange Fruit (Citrus Sp.) In Major Cities in Oyo State, Nigeria
}

\author{
Olaniran O. ${ }^{1 *}$ Ojo O. A $^{1}$ and Odelade K. A $^{2}$ \\ ${ }^{I}$ Department of Agronomy, Ladoke Akintola University of Technology, P.M.B 4000, Ogbomoso, Nigeria \\ ${ }^{2}$ Department of Pure and Applied Biology, Ladoke Akintola University of Technology, P.M.B 4000, Ogbomoso, \\ Nigeria
}

\begin{abstract}
Survey and collection of the marketed orange fruit with rot symptoms were conducted in the South Western Nigeria in 2011 and 2012 respectively. Orange fruits showing rot symptoms that are displayed for sale in five different market places in five major cities in Oyo State in South Western Nigeria namely, Ogbomoso, Oyo, Saki, Ibarapa and Ibadan were collected and examined for the presence of the inducing pathogens as well as aflatoxin contamination. Fourteen pathogenic fungi were isolated from rotted orange fruits were: Aspergillus flavus, Aspergillus niger, Botryodiplodia theobromae, Botrytis cinerea, Curvularia lunata, Fusarium oxysporium, Fusarium moniliforme, Geotrichum spp., Penicillium citrinum, Penicillium digitatum, Rhizopus stolonifer, Trichoderma viridae, Phytopthora spp and Rhizopus nigricans. A. flavus, A. niger, F. oxysporium, $F$. moniliforme, Geotrichum spp, $P$. digitatum, $P$. citrinum and $R$. nigricans respectively had the significantly $(P \geq 0.05)$ highest rate of occurrence among the isolated fungi while Trichoderma viridae and Curvularia lunata were significantly $(P \geq 0.05)$ least encountered in this study. Pathogenicity tests revealed that of all isolated fungi, Aspergillus flavus, Fusarium oxysporium, Rhizopus nigricans, Fusarium moloniforme, Geotrichum spp., Penicillium citrinum and Rhizopus stolonifer were highly pathogenic with the first three leading to rapid disintegration of treated fruit in 3-5 days, while the rest were moderately pathogenic with the exception of $P$. oxalicum and $T$. viride that caused the least significantly pathogenic rot of orange fruits.

Quantities of aflatoxins were detected from infected orange fruits, collected from all the markets in each city in Oyo state.
\end{abstract}

Keywords: Citrus sinensis, Aflatoxins, Post-Harvest Diseases, Survey.

\section{Introduction}

Citrus is a tropical plant cultivated extensively in the sub-tropics with a Mediterranean climate (Mary et al, 2003). Its fruits have been reported by Jim (2003) as very economically valued fruits among the. According to Nicole (2000), the fruits are used in making fruit salad and fruit juice. In addition, their essential oils are used in the cosmetic and pharmaceutical industries (Frazier and Westhote, 1978) .In the whole world, the postharvest rots of these fruits have been extensively studied. (Fatemi, 1972; Ezeibekwe and Unamb, 2009) reported Citrus fruits decline in Iran due to fruit rot incited by Pythium aphanidermatum (edson) fitz; and Phytophthora citrophthora (Butler) Leonian favaloro and Somma (1971) described Phytophthora syringae Kleb, P. citricola Sawada and P. citrophthora as the most widespread citrus fruit rot pathogens in Italy. Graham and Tummer (1994) also described Phytophthora nicotianae and P. citrophthora as the most common causal organisms of brown rot of Citrus fruits in Florida. Timmer and Menge (2000) implicated P. citricola Sawada, P. citriophthora (R.E. Sm \& E.H. Sm) Leonian, P. hibernalis Carne, and P. nicotianae Breda de Haan var. parasitica (Dastur) as causal agents of brown rot of fruits. They also described Botryodiplodia theobromae (Pat.) Griffon and Maubl as stem end rot pathogen. Fusarium oxysporum Schlechtend Fr. F. sp. citri was also described by them as a causal organism of dry fruit rot of Citrus. Nzekwe (1996) found out that Fusarium spp, Curvularia spp, Aspergillus spp and Penicillum spp cause Citrus fruit rots in Abia State of Nigeria. Dim (2004) isolated and recorded Aspergillus spp, B. theobromae, Botrytis cinerea Pers. Fr., Fusarium spp, Phytophthora spp, Rhizopus stolonifer (Ehrenh fr) Vuill, Syncephalastrum racemoses, Gloesporium nervisequum and Mucor racemosus in some harvested Citrus fruits in some cities in Oyo State of Nigeria.

In the Southern part of Nigeria, orange fruit production has improved the diet of the local people, whose diet generally consisted of starch staples lacking essential vitamin and minerals (Baiyewu, 1994). There has been a great increase in the demand for orange fruits over the years and this may be due to their increased consumption pattern in the tropic (Adisa, 1983, Ezeibekwe and Unamb, 2009). Orange fruit is usually grown in the wild and harvested by local farmers using long sticks into a large open baskets or fibre bags (Adisa, 1983). The baskets /fibre bags may be contaminated with spoilage fungi and are often piled on top of one another during transportation, resulting to bruising and squeezing of fruit (Baiyewu et al., 2007; Akinmusire, 2011). 
Bruised fruits readily become colonized by propagules of the pathogens associated with the fruit surfaces and those in the fluids leaking from already rotten fruit (Arekemase and Oyeyiola, 2007). These orange fruits were usually displayed on benches and in baskets for prospective customers in the open markets until sold, thereby exposing them to further microbial infection (Baiyewu and Amusa, 1999) beside those associated with the fruit surface and those from adjacent infected fruits (Baiyewu, 1994). A visit to most of these markets revealed that between 20 and $45 \%$ of fruit displayed for sale showed symptoms microbial infection. These fungal infected orange fruit were sold at lower prices and were usually preferred by the low-income earners. In Nigeria, Adisa and Fajola (1982) implicated Penicillium digitatum, P. citrinum and Botrydiplodia theobromae as pathogens of Citrus fruit rots in South Western Nigeria. Besides the losses in income to the orange fruit marketers, the rotten fruits could also cause a health hazard to consumers (Elegbede and Gould, 2002; Bankole and Adebanjo, 2003; Ojo and Adebayo, 2009). Krogh (1992) has earlier reported that most microbes infecting plant tissues often produced secondary metabolites in their hosts, which are known to be hazardous to animals including man. Some of these metabolites include the ergot alkaloids on cereals by Clavisep sp, fumonisin on maize by Fusarium sp, aflatoxins and ochratoxins on several plants produced by Aspergillus sp. (Prasad, 1992). Aflatoxins, which are a group of highly toxic, mutagenic and carcinogenic polyketide compounds, were first reported in groundnut feed that poisoned thousands of poultry and pigs (Goldblatt and Stoloff, 1983). In addition, it has been reported that mycotoxins were detected from Pawpaw fruits inoculated with Rhizopus, Aspergillus, and Fusarium before and after auto claving for 15 minutes and at $121^{\circ} \mathrm{C}$ (Oyeyipo et al., 2012). This research was therefore embarked upon to survey the post-harvest deterioration and aflatoxin contamination of orange fruit sold in popular markets in Oyo state, South Western Nigeria.

\section{Fruit source and isolation of fungi}

\section{Materials And Methods}

Orange fruits both fresh and those found with symptoms of fungal infection were purchased from five different markets located in five different cities in Oyo state; Ogbomoso, Oyo, Saki, Ibarapa and Ibadan respectively of Nigeria. These cities are located in low humid part of South Western Nigeria. The vegetation is typically tropic, the climate is characterized by dry November to April and wet May to October seasons. The mean annual rainfall of 1150 - $1500 \mathrm{~mm}$ occurs mainly between April and October with the major peak in June. Higher relative humidity $(\mathrm{rH})$ values $(\mathrm{rH} 80-95 \%)$ are recorded during the rainy season than the dry season $(\mathrm{rH}$ $20-50 \%$ ). A total of 90 randomly selected fungal infected fruits and 90 unblemished, healthy and clean looking fruits were purchased (10 each from each market). Fruits were surface sterilized by exposing them in $1 \mathrm{~min} 90 \%$ ethyl alcohol (BDH chemicals Ltd Poole England) and then 3 min to 1\% sodium hypochlorite and then rinsed three times in sterile distilled water. Segments $(3-5 \mathrm{~cm})$ of tissues from the margins of the rotted areas were cut out with a sterile scalpel and placed on previously prepared potato dextrose agar (PDA, Difco) in Petri dishes and incubated at $28 \pm 1 \mathrm{oC}$ for 5 days under $12 \mathrm{~h}$ photoperiod. The fungal colonies that appeared were primarily identified using cultural and morphological features (Barnett and Hunter, 1972; Baiyewu and Amusa, 2007). This experiment was conducted in year 2011 and 2012 respectively.

\section{Pathogenicity of isolated fungi}

Thirty (30) healthy orange fruits collected from the each study sites were surfaced sterilized in ethyl alcohol as described above. Fruits were wounded with a sterile $5 \mathrm{~mm}$ cork borer, and inoculated with mycelia disc (3 $\mathrm{mm}$ in diameter) of the fungal test isolate. The inoculated wound was sealed with Vaseline petroleum jelly. The inoculation was done in a laminar flow chamber. Five orange fruits were inoculated each with each of the isolates and this experiment was replicated three times. Controls consisted of five fruits wounded with the sterilized cork borer but not inoculated. The inoculated fruits and the controls were placed in clean polyethylene bag (one fruit per bag) each moistened with wet balls of absorbent cotton wool to create a humid environment and incubated at $30 \pm 1^{\circ} \mathrm{C}$ for 5 days. After $72 \mathrm{~h}$, the inoculated fruits were observed for symptom development. The causal agents were re-isolated from the infected orange fruit and compared with the original isolates.

\section{Aflatoxin detection using thin layer chromatography}

Ten grammes $(10 \mathrm{~g})$ each of the rotten sample orange fruits obtained from each of the markets, as well as from clean (non- infected fruits) inoculated with the fungal isolates respectively were extracted with chloroform (May and Baker (Ltd) England) and concentrated (Muhammad et al., 2004) . Of the extracted samples, 5, 10 and 15 L were spotted on three different points on a ruled base line of the thin layer chromatography (TLC) coated with plates silica gel (Merck ${ }^{\circledR}$ TLC grade7749) (Muhammad et al., 2004). Also 5,10 and 15 L of the aflatoxin standard were spotted on another three points near the previous sample extract spotted points (Muhammad et al., 2004). These were then developed in TLC tanks containing the solvents (toluene, isoamyl alcohol and methanol) at a ratio of 3: $3: 2$. When the solvent emigrated to about $2 / 3$ of the plates, the plates was removed, air dried and examined under UV light at a distance of $365 \mathrm{~mm}$ (Fennell et al., 
1973). The aflatoxin levels were semi-quantified based on comparisons with control levels, while the presence of aflatoxin in orange samples from various sampling centers were determined.

\section{Statistical analysis}

The data obtained were subjected to statistical analysis and the means were separated using Duncan's multiple rage test (DMRT) at 5\% of probability.

\section{Results And Discussion}

Results of this study showed that Aspergillus flavus, Aspergillus niger, Botrydiplodia theobromae, Botrytis cinerea, Curvularia lunata, Fusarium oxysporium, Fusarium moniliforme, Geotrichum spp., Penicillium oxalicum, Penicillium citrinum, Rhizopus stolonifer, Trichoderma viridae, Phytopthora spp, and Rhizopus nigricans were found to be associated with marketed orange fruits in Oyo State Southwestern Nigeria (Figure 1). The incidence of occurrence of these pathogens in the five markets in each of the Cities was not significantly $(\mathrm{P} \geq 0.05)$ between 2011 and 2012 respectively.

In the Northern guinea savannah of South Western Nigeria, the high rainfall pattern, high humidity and the temperature of between 19 and $31^{\circ} \mathrm{C}$ prevailing in the agro ecology favors the development of fungal diseases both in the field and the market. The isolation of these pathogens confirmed the studies of Gupta and Pathak (1986) and Kuthe and Spoerhase (1974) that R. nigricans, A. niger, C. lunata, A. flavus, F. moniliforme, and $\mathrm{C}$. capsici found associated with rotten orange are highly pathogenic causing appreciable losses in orange fruits at post harvest. Ezeibekwe and Unamb (2009) also isolated Fusarium spp., A. flavus, Rhizopus spp., Botryodiplodia and Curvularia spp. from orange fruit. In our studies, the pathogenicity test revealed that all isolated fungi R. nigrican, F. moniliforme, C. capsici and C. lunata proved highly pathogenic causing a rapid disintegration of inoculated fruits in three to five days. A. niger was moderately pathogenic while the least pathogenic was T. viridae and A. flavus (Figure 2). However, from the result of this study, P. oxalicum and T. viridae are not likely to be pathogens of orange fruit but rather contaminants. Hence necessary precaution in preventing contamination of this produce by these fungi will enhance the microbial quality of the produce.

The result on the detection of aflatoxin rotten orange fruit obtained from major cities in Oyo state, Nigeria is presented in Table 1. The result showed that aflatoxin was detected from all the rotted orange obtained from all the major markets in cities in Oyo state.

The TLC spot extracted from most of the infected orange fruit, A. flavus inoculated fruits and the standard aflatoxin fluoresces produced bluish spots of equal intensities. Fungi have been discovered to produce secondary metabolites in plants tissues potentially harmful to humans and animals (Eaton and Groopman, 1994). Aflatoxin has been associated in cancer of the liver (heptatoma) and also with acute hepatitis in humans, especially in the developing world (Eaton and Groopman, 1994; Krogh, 1992; Prasad, 1992; Funnell et al., 1973). Aflatoxin was detected in $80 \%$ of the sampled orange fruits(Table 1).The detection of aflatoxins in the market orange fruits and the high incidence of A. flavus isolated from infected fruit (Figure 1) strongly suggest that A. flavus might be the main producer of these toxins. Other fungal isolates found associated with these orange fruits have never been reportedly associated with aflatoxin production. A. flavus has been reportedly isolated from orange fruits in Nigeria (Ezeibekwe and Unamb, 2009). Aflatoxins have been reportedly detected in grapes, tomatoes and oranges in France (Sage et al., 2002; Muhammad et al., 2004). Singh (1983) reported that out of 342 samples of different fruits and spices obtained from the stores of commercial centers screened for aflatoxin, 95 of them were positive. Post harvest handling and transport of orange fruit is inadequate, particularly in the market surveyed in this study. Therefore most of the orange fruits harvested do not usually get to the major cities in time due to the nature of transport systems existing in the rural areas. While fruit with bruises are not isolated from the un-bruised ones and thereby causing cross-infections, consumers are supplied mostly with partly rotten fruits. Low-income earners who cannot afford the price of the non-infected or clean oranges mostly consume the partly rotten fruits. The fact that most people have not been diagnosed as having hepatoma or aflatoxicosis does not mean that the toxic metabolite does not exist in their body system (Muhammad et al., 2004; Oyeyipo et al., 2011). To date, no tests have been conducted if aflatoxins are in the urine and blood to determine the presence and risk of such metabolites in most working class people in this region. Aflatoxin M1, for example, has been reportedly detected in the urine the Philippine women that consumed peanut butter containing aflatoxin (Sage et al., 2002). It is therefore important that both the farmer who harvests the fruits into bags for transportation, the marketers and consumers take necessary precaution in preventing contamination and eating of contaminated fruits thereby reducing the risk of aflatoxin and other mycotoxins that are deleterious to human health. 


\section{References}

[1]. Adisa K.A, Fajola A.O (1983). Cellulolytic enzymes associated with the soft rots of Citrus sinensis caused by Aspergillus aculeatus and Botryodiplodia theobromae. Mycopathologia 82: 23-27.

[2]. Adisa, V.A and Fajola, A.O (1982). Post harvest fruit rot of three species of Citrus in South Western Nigeria. Indian phytopath. Department of Botany, University of Ibadan 35(4):595-603.

[3]. Akinmusire, O.O (2011). Fungal Species Associated with the Spoilage of Some Edible Fruits in Maiduguri Northern Eastern Nigeria. Advances in Environmental Biology, 5(1): $\quad$ 157-161, 2011 ISSN 1995-0756.

[4]. Baiyewu R.A, Amusa N.A (1999) Biochemical changes in pawpaw fruits (VAR. ISOLO, JS22 and HOMESTEAD) infected with fungi Bioscience Research Communications 11(3): 257-261

[5]. Baiyewu R.U (1994). Fungi associated with fruit rot of pawpaw in southwestern Nigeria. PhD. Thesis, University of Ibadan, Nigeria p. 145 .

[6]. Bankole S. S and Adebanjo A, (2003). Mycotoxins in food in West Africa: current situation and possibilities of controlling it. African J. Biotechnology 2: 254-63

[7]. Barnett H.C, Hunter B.B (1972). Illustrated Genera of Imperfect Fungi $3^{\text {rd }}$ edition. Minneapolis Burgress Publishing Company Minneapolis, MN, p. 241.

[8]. Dim, M.U (2004). A survey of diseases of Citrus in Owerri zone of Imo State. Project work, Department of Plant Science and Biotechnology, Imo State University. P vi

[9]. Eaton D.L, Groopman J.D (1994). The toxicology of Aflatoxins, Academic Press, New York, NY, pp. $383-424$.

[10]. Elegbede, J.A and Gould, N. M (2002). Monoterpenes reduced addicts formation in rats exposed to aflatoxin Bi. African Biotechnology 1: 46-9.

[11]. Ezeibekwe, I.O and Unamb, C.I (2009). Pathogens Associated with Citrus Fruits Rots in Imo States, Nigeria. Journal of America Science 5(4): 129-132.

[12]. Frazier, W.C and Westhofe, D.C (1978). Contamination, preservation and spoilage of vegetables and fruits. Food Microbiology. New York. McGraw Hill Book Company, $3^{\text {rd }}$ edition 12:194-214.

[13]. Funnell D.I, Borthast R.J, Lillehij E.B, Paterson R.E (1973). Bright greenish-yellow fluorescence and associated fungi in corn naturally contaminated with aflatoxin. Cereal Chem. 50:404-414.

[14]. Goldblatt, Stoloff (1983). History and occurrence of aflatoxins" in Naguib, M.M., Park,D.L and Pohland, A. E.(Eds) Proceeding s of International Symposium on mycotoxins, General organization for Government Printing Offices Cairo. pp. 33-46.

[15]. Graham, J.M and Timmer, L.W (1994). Phytophythora diseases of Citrus. A series of the plant pathology department. Florida Cooperative Extension Service, Institute of Food and Agricultural Science, University of Florida. Life Science, University of Arizona.

[16]. Gupta A.K, Pathak V.N (1986). Survey of fruit market for papaya fruit rot by fungi pathogens. Indian J. Mycol. 16:152-154.

[17]. Krogh P (1992). Adverse effect of mycotoxins on human health in: seed pathology. In Mathur, S. B. and Jorgensen, J. (Eds), Proceedings of the seminar, 20-25 June 1988, Copenhagen, Denmark, pp. 149-57.

[18]. Kuthe G, Spoerhase H (1974). Cultivation and use of pawpaw (Citrus spp. L).Tropen Land Writ. 75:129-139.

[19]. Muhammad S, Shehu K, Amusa N.A (2004). Survey of the market diseases and aflatoxin contamination of Tomato (Lycopersicon esculentum MILL) fruits in Sokoto North Western Nigeria. Nutrition and Food Sci. (UK) 34:72-76.

[20]. Nzekwe (1996). Diseases of Citrus sinensis fruit. Project work, Department of Botany, Abia State University. Pp 11-31. Prasad T (1992). Plant pathogenesis and disease control. Plant Dis. J. of Japan Acado. 56:367.

[21]. Ojo, O.A and Adebayo, T.A (2009). Mycotoxigenic fungal species associated with stored groundnut and the levels of aflatoxin. Journal of sustainable Agriculture 65(1): 22-3

[22]. Sage L, Krivobok S, Delbos E, Seigle-murandi F, Creppy EE (2002). Fungal floral and Ochratoxin A production in grapes and musts from France. J. Agric. Food Chem. 50:1306-1311.

[23]. Singh A. (1983). "Mycotoxin contamination in dry fruits and spices" in Bilgrami KS, Prasad T, Sinha KK (Eds) Proceedings of International Symposium on mycotoxin in Food and Feed, Allied Press, Bhagalpur, pp. 55-68.

[24]. Timmer, L.W and Menge, J.A (2000). Common names of plant diseases. Diseases of Citrus APS Interactive Careers and Placement. Journal and News Online Resources Kagawa APS Press Bookstore.

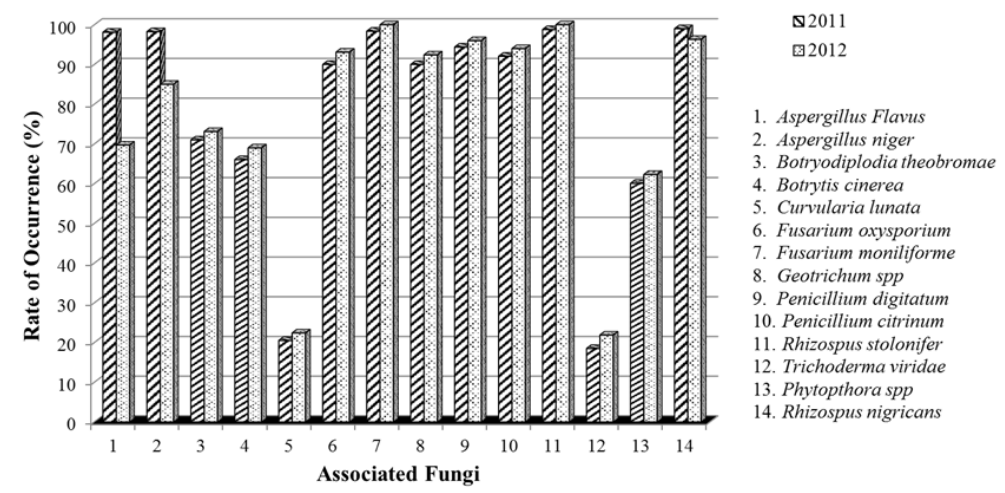

Fig 1: The rate of occurrence of pathogenic fungi associated with rotted orange fruits in different cropping year 

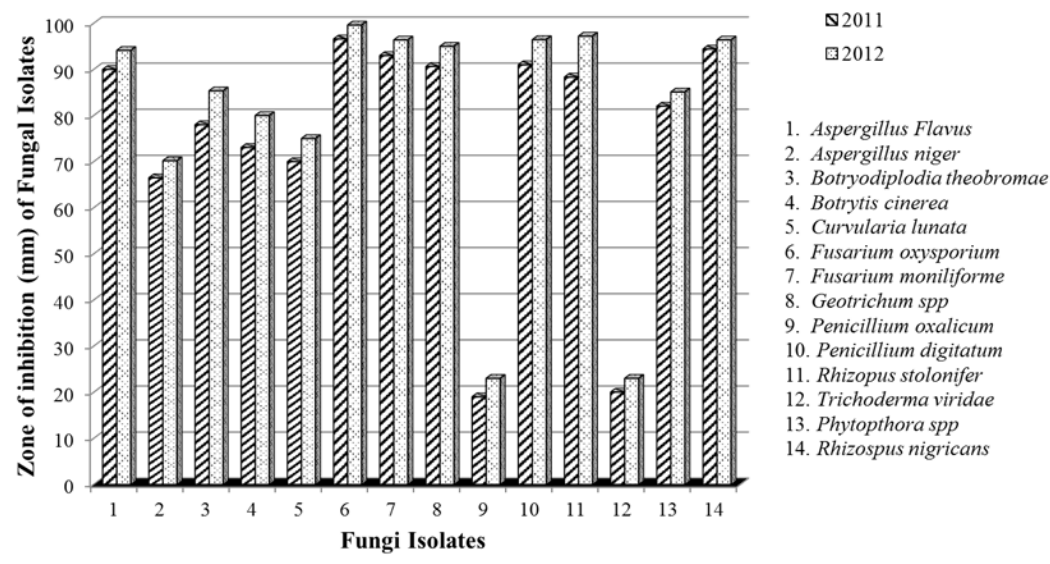

Fig 2: The pathogenicity of fungi associated with rotted orange collected from different markets in major cities of Oyo state, Nigeria.

Table 1: Detection of aflatoxin in rotten orange fruit obtained from the market places in major cities in Southwestern Nigeria.

\begin{tabular}{|c|c|c|c|c|}
\hline \multirow[t]{2}{*}{ Markets } & \multicolumn{2}{|c|}{2011} & \multicolumn{2}{|c|}{2012} \\
\hline & $\begin{array}{l}\text { Rotten orange } \\
\text { Fruits }\end{array}$ & $\begin{array}{c}\text { Fresh orange } \\
\text { fruits }\end{array}$ & $\begin{array}{c}\text { Rotten orange } \\
\text { Fruits }\end{array}$ & $\begin{array}{l}\text { Fresh orange } \\
\text { fruits }\end{array}$ \\
\hline Oje market & + & - & + & - \\
\hline Apata & - & - & - & - \\
\hline Yemetu & + & - & + & - \\
\hline Sango & + & - & + & - \\
\hline Oja'ba & + & - & + & - \\
\hline Akesan market & + & - & + & - \\
\hline Ojongbodu & + & - & + & - \\
\hline Isale Oyo & + & - & + & - \\
\hline Oyo central & + & - & + & - \\
\hline Asipa market & + & - & + & - \\
\hline Arada market & - & - & - & - \\
\hline Sabo market & + & - & + & - \\
\hline Owode market & + & - & + & - \\
\hline Akande market & + & - & + & - \\
\hline Abogunde market & + & - & + & - \\
\hline Owode market & + & - & + & - \\
\hline Oja-Oba market & + & - & + & - \\
\hline Shaki central & + & - & + & - \\
\hline Sabo market & + & - & + & - \\
\hline Ajebamidele market & + & - & + & - \\
\hline Oja-Oba market & + & - & + & - \\
\hline Owode market & + & - & + & - \\
\hline Ibarapa central & + & - & + & - \\
\hline Sabo market & + & - & + & - \\
\hline Balogun market & + & - & + & - \\
\hline
\end{tabular}

Note:

$\begin{array}{lll}- & = & \text { Aflatoxin positive } \\ & \text { Aflatoxin negative }\end{array}$ 